\title{
OLM interneurons differentially modulate CA3 and entorhinal inputs to hippocampal CA1 neurons
}

\author{
Richardson N Leão ${ }^{1,2}$, Sanja Mikulovic ${ }^{1}$, Katarina E Leão ${ }^{1,2}$, Hermany Munguba ${ }^{2}$, Henrik Gezelius ${ }^{1}$, \\ Anders Enjin ${ }^{1}$, Kalicharan Patra ${ }^{1}$, Anders Eriksson ${ }^{1}$, Leslie M Loew ${ }^{3}$, Adriano B L Tort ${ }^{2}$ \& Klas Kullander ${ }^{1,4}$
}

\begin{abstract}
The vast diversity of GABAergic interneurons is believed to endow hippocampal microcircuits with the required flexibility for memory encoding and retrieval. However, dissection of the functional roles of defined interneuron types has been hampered by the lack of cell-specific tools. We identified a precise molecular marker for a population of hippocampal GABAergic interneurons known as oriens lacunosum-moleculare (OLM) cells. By combining transgenic mice and optogenetic tools, we found that OLM cells are important for gating the information flow in CA1, facilitating the transmission of intrahippocampal information (from CA3) while reducing the influence of extrahippocampal inputs (from the entorhinal cortex). Furthermore, we found that OLM cells were interconnected by gap junctions, received direct cholinergic inputs from subcortical afferents and accounted for the effect of nicotine on synaptic plasticity of the Schaffer collateral pathway. Our results suggest that acetylcholine acting through OLM cells can control the mnemonic processes executed by the hippocampus.
\end{abstract}

The hippocampus is a brain region that is involved in spatial navigation and memory formation ${ }^{1,2}$, but the network mechanisms underlying these functions are not well understood. Recent evidence suggests that the control of pyramidal cell activity by GABAergic interneurons is required for the execution of hippocampal functions $^{3,4}$. Hippocampal interneurons are a diverse population of cell types that have distinct postsynaptic domains and therefore differentially control input/output activity ${ }^{5}$; the precise roles of the distinct inhibitory cell types are currently unclear. The classification of hippocampal interneurons through their expression of proteins and peptides, including parvalbumin (PV), calretinin, calbindin, somatostatin (SOM), vasoactive intestinal peptide and neuropeptide $\mathrm{Y}$, has been a major framework for studying interneuron function ${ }^{6,7}$. To date, however, no single molecular marker is specific for any interneuron subtype, as defined by their pattern of pyramidal cell innervation. For example, $\mathrm{PV}^{+}$cells include basket, bistratified and axo-axonic cells ${ }^{6}$, which target pyramidal cells at different subcellular compartments. In light of modern genetic techniques that can enhance or suppress cellular activity ${ }^{8}$, finding specific molecular markers for morphologically well-defined subtypes of GABAergic interneurons is important for understanding their role in information processing.

OLM cells are a major class of GABAergic interneurons in the outermost layer of the hippocampus (stratum oriens) with perpendicular axonal projections to the innermost layer (stratum lacunosummoleculare, SLM $)^{5}$. CA1 OLM cells inhibit the distal apical dendrites of pyramidal cells, the same cellular compartment where the direct input originating from layer III of the entorhinal cortex arrives, forming the temporoammonic pathway ${ }^{9}$. OLM cells have been hypothesized to coordinate cell assemblies ${ }^{10}$ and to produce theta oscillations ${ }^{11,12}$, cross-frequency coupling ${ }^{10,13}$ and gating of longterm potentiation (LTP) ${ }^{14}$. However, despite insights derived from computer simulations ${ }^{10,15}$, the function of OLM cells has not been directly demonstrated.

Notably, OLM cells are highly sensitive to nicotine ${ }^{14}$, but it is currently unknown whether cholinergic neurons from the medial septum and diagonal band of Broca (MS-DBB), the major source of acetylcholine to the hippocampus, directly target nicotine receptors in OLM cells. To the best of our knowledge, no functional study has yet shown fast cholinergic inputs originating from the MS-DBB to any known type of hippocampal neuron. It is currently believed that subcortical cholinergic afferents are mainly neuromodulatory, acting through slow metabotropic receptors ${ }^{16}$. In vitro, however, nicotine facilitates LTP of Schaffer collateral synapses onto CA1 pyramidal cells through receptors containing the nicotinic acetylcholine receptor $\alpha 2$ subunit (CHRNA2), which are exclusively present in stratum oriens ${ }^{14,17,18}$. Recent evidence suggests that CHRNA2 may be specifically expressed in OLM cells, which, in turn, could underlie the enhancement of Schaffer collateral-CA1 LTP by nicotine ${ }^{14,19}$. Thus, direct cholinergic excitation of OLM cells might be involved in switching the information flow in CA1 from direct entorhinal cortex inputs carrying sensory information (temporoammonic pathway) to inputs carrying internal representations stored in CA3 (Schaffer collateral pathway) ${ }^{15}$.

To investigate this hypothesis, we generated a mouse line expressing Cre recombinase under the control of the Chrna2 promoter (Chrna2-cre). We found that CHRNA2 is a molecular marker that is specific for CA1 OLM cells in the hippocampus. Furthermore, we found that CA1 OLM cells inhibited distal portions of CA1 pyramidal cell dendrites while disinhibiting proximal dendrites,

${ }^{1}$ Developmental Genetics, Department of Neuroscience, Uppsala University, Uppsala, Sweden. ${ }^{2}$ Brain Institute, Federal University of Rio Grande do Norte, Natal, Brazil. ${ }^{3}$ R.D. Berlin Center for Cell Analysis and Modeling, UConn Health Center, Farmington, Connecticut, USA. ${ }^{4}$ Science for Life Laboratory, Department of Neuroscience, Uppsala University, Uppsala, Sweden. Correspondence should be addressed to K.K. (klas.kullander@neuro.uu.se) or R.N.L. (richardson.leao@neuro.uu.se). 
Figure 1 Chrna2 is a marker for CA1 OLM interneurons. (a) Photomicrograph of a horizontal hippocampal slice of a Chrna2-cre; R26tom mouse showing the distribution of Tomato+ cell bodies in stratum oriens (SO). Note the dense axonal arborizations of Tomato $^{+}$cells in SLM and the absence of Tomato $^{+}$cell bodies in CA3 or dentate gyrus (DG). Scale bar represents $100 \mu \mathrm{m}$. (b) Reconstruction of a biocytin-filled Tomato ${ }^{+}$ neuron (dendrites, red; axon, black; scale bar represents $20 \mu \mathrm{m}$ ). Inset, typical membrane response of a hippocampal Tomato+ neuron to hyper- and depolarizing current injection (scale bars represent $100 \mathrm{~ms}, 15 \mathrm{mV}$ ). SP, stratum pyramidale; SR, stratum radiatum. (c) Left, diagram of experimental setup with temporoammonic stimulation (TA stim; red) and green box delineating where VSD imaging was performed. The hippocampus diagram was adapted from ref. 47. Middle, VSD fluorescent responses to temporoammonic stimulation (ten pulses, $20 \mathrm{~Hz}$ ) were measured at rectangular regions in stratum radiatum (black) and SLM (red). The excitation spread was defined as the ratio between the fluorescence variation in stratum radiatum and SLM, measured $50 \mathrm{~ms}$ after stimulus onset. Right, comparison of Chrna2-cre (1) and Chrna2-cre; ViaatloxP/loxP (2) mice. Error bars denote \pm s.e.m. ${ }^{*} P<0.05$. (d) Top, expression of ChR2/YFP in Chrna2-cre cells in a hippocampal slice used for VSD imaging and optogenetic stimulation of OLMChR2 cells. Scale bar represents $50 \mu \mathrm{m}$. Bottom left, fluorescence changes at stratum radiatum following Schaffer collateral stimulation with or without application of a 1.4-mW laser light pulse. Bottom right, excitation of OLMChR2 cells with light produced an increase in the depolarization at stratum radiatum following Schaffer collateral stimulation measured as the area under the curve of the fluorescence signal change in response to Schaffer collateral stimulation.

(e) Schematic and image of a pyramidal cell (PC) dendritic voltage-clamp recording at stratum radiatum (left). Recordings of typical traces show excitation from AMPA EPSCs (isolated by blocking NMDA with AP5) elicited by Schaffer collateral (SC) stimulation in control (black) and during blue light stimulation (horizontal bar) targeted at CA1 stratum oriens (red). The box plot shows increased summation of AMPA-mediated EPSCs during blue light stimulation of the CA1 stratum oriens region (red) compared with no light stimulation (black). Scale bar represents $20 \mu \mathrm{m}$.

modulated synaptic efficiency and plasticity of entorhinal cortex and CA3 inputs, and were excited by fast cholinergic transmission.

\section{RESULTS}

OLM cells were observed by Ramon y Cajal, but their network function remains elusive. To date, the most used marker for OLM cells is SOM; however, SOM is also expressed in other interneuron subtypes found in stratum oriens, as well as in stratum pyramidale and stratum radiatum of CA1 and CA3, and in the dentate gyrus ${ }^{5}$ (Supplementary Fig. 1). A recent study hypothesized that CHRNA2 may be specifically expressed in OLM cells ${ }^{14}$. Consistent with this, in situ hybridization has shown that Chrna 2 mRNA is restrictively found at CA1 stratum oriens in the hippocampus of mice ${ }^{17}$. To investigate whether Chrna2 is a specific marker of CA1 OLM cells, we used Chrna2-cre mice. Histological analysis of the hippocampi of mice expressing the red fluorescent protein Tomato under the control of Cre (Chrna2-cre) $R 26^{\text {tom }}$ ) revealed that Tomato $^{+}$cells in the hippocampus were almost exclusively located in the stratum oriens of CA1 and subiculum (Fig. 1a and Supplementary Fig. 1a), whereas cells expressing somatostatin mRNA (Som, also known as Sst) were found in multiple strata of all hippocampal regions (Supplementary Fig. 1b). In situ hybridization for Som combined with immunohistochemistry for Tomato revealed that the vast majority $\left(95.1 \%, 214 / 225\right.$ cells) of Tomato ${ }^{+}$cells were also $\mathrm{Som}^{+}$and comprised a subpopulation (35.2\%, 214 of 608 neurons) of CA1 Som ${ }^{+}$interneurons (Supplementary Fig. 1c,d).

Reconstructions of biocytin-filled Tomato ${ }^{+}$neurons (Fig. 1b) typically $(87.6 \%, 148$ of 169$)$ displayed OLM cell morphology, that is, cell bodies and horizontal dendrites in stratum oriens and axons running perpendicularly to SLM, where they branched considerably and terminated. The remaining neurons had morphologies compatible
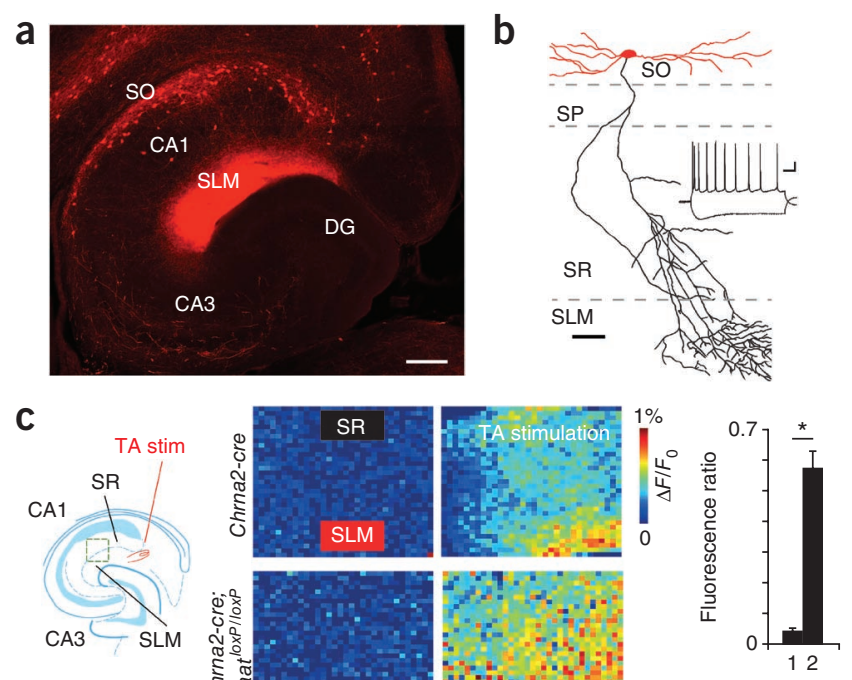

d
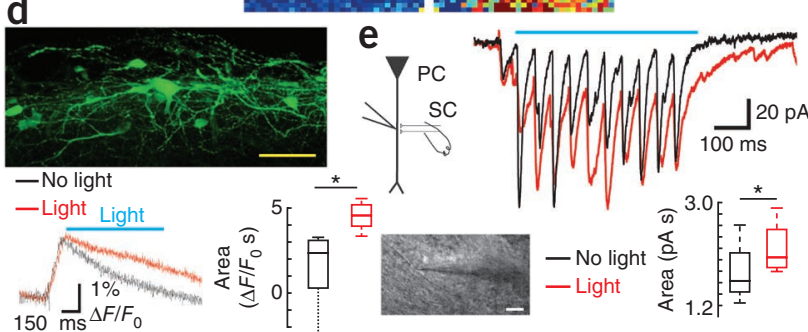

with pyramidal cells $(4.1 \%)$, and trilaminar (4.1\%), bistratified $(1.8 \%)$ and stratum radiatum $(2.4 \%)$ interneurons. Tomato $^{+}$cells $(n=126)$ displayed mean input resistance of $293.3 \pm 9.6 \mathrm{M} \Omega$, resting membrane potential of $-60.3 \pm 0.3 \mathrm{mV}$, capacitance of $31.5 \pm 0.7 \mathrm{pF}$, low-frequency discharge and a 'sag' in response to hyperpolarizing current injection (Fig. 1b), which are membrane properties typical of OLM cells ${ }^{20}$. These neurons fired spontaneous action potentials at low frequencies $(1.1 \pm 0.2 \mathrm{~Hz}$ in whole-cell recordings, $n=15 ; 4.3 \pm$ $1.0 \mathrm{~Hz}$ in cell-attached recordings, $n=10)$. Single-cell reverse transcription PCR to detect glutamic acid decarboxylase 67 (Gad67, also known as Gad1) mRNA ( $n=25$ of 25 neurons) and in situ hybridization for vesicular inhibitory amino acid transporter (Viaat, also known as Slc32a1) mRNA (Supplementary Fig. 2a) confirmed the inhibitory nature of the Tomato ${ }^{+}$cells. Together, these results indicate that Chrna2-cre-driven $\mathrm{Tomato}^{+}$expression was highly specific for OLM cells in the CA1 region and subiculum. These cells are hereafter referred to as $\mathrm{OLM}^{\alpha 2}$ cells.

\section{OLM cells gate CA1 inputs}

Morphological and electrophysiological data have shown that OLM cells exert strong inhibition onto distal portions of pyramidal cell apical dendrites 9 . To corroborate these findings, we loaded pyramidal cells with the intracellular voltage-sensitive dye (VSD) JPW3028 (ref. 21) and QX314 (to block action potentials) while triggering action potentials in connected OLM ${ }^{\alpha 2}$ cells. Depolarization of dendrites was achieved by pyramidal cell somatic current injection (100 pA, $400 \mathrm{~ms}$ ). We examined the spatial distribution of OLM ${ }^{\alpha 2}$ cell inhibition onto pyramidal cell dendrites by triggering action potentials in connected OLM ${ }^{\alpha 2}$ cells at the end of the pyramidal cell depolarization current step. As expected, we found that OLM ${ }^{\alpha 2}$ 
Figure 2 OLM $\alpha 2$ cells inhibit interneurons that synapse on pyramidal cell proximal dendrites. (a) Schematic of experimental setup (upper left). IPSCs in a stratum radiatum interneuron (RN) were elicited by 20-ms light pulse stimulation of OLM $\alpha 2$ cells transduced with Cre-inducible hChR2 (OLMChR2). Glutamatergic EPSCs were blocked by AP5 and CNQX. Application of PTX abolished the postsynaptic response to blue light. Inset, action potentials triggered in an OLMChR2 cell by a 20-ms light pulse. (b) Current-clamp recordings showing EPSPs in the same stratum radiatum interneuron as in a (black) elicited by Schaffer collateral stimulation (arrows). Stratum radiatum interneuron spiking elicited by concomitant current injection during Schaffer collateral stimulation lowered postsynaptic pyramidal cell responses, as evidenced by voltage imaging of pyramidal cells electroporated with VSD. Changes in potential were measured at the region of interest delimited by the green rectangle shown on the top right micrograph. Scale bar represents $20 \mu \mathrm{m}$.

(c) Bottom, reconstruction of the stratum radiatum interneuron (filled with biocytin) shown in $\mathbf{a}$ and $\mathbf{b}$. Scale bar represents $50 \mu \mathrm{m}$. Top, confocal imaging showing synaptic contacts (arrows) between OLM cell axons (red) and stratum radiatum interneuron dendrites (green). Scale bar represents $20 \mu \mathrm{m}$. (d) IPSCs in a bistratified interneuron (BS) elicited by 20-ms light pulse stimulation of OLMChR2 cells. The reconstruction of the bistratified interneuron is shown on the top left panel. Scale bar represents $50 \mu \mathrm{m}$.

cell spikes inhibited pyramidal cells mainly at the distal apical dendrite (mean fluorescence change in the distal dendrite: pyramidal cells without OLM ${ }^{\alpha 2}$ spikes, $0.6 \pm 0.02 \% \Delta F / F_{0}$; pyramidal cells with $\mathrm{OLM}^{\alpha 2}$ spikes, $0.4 \pm 0.04 \% \Delta F / F_{0} ; n=4, t_{3}=8.36, P=0.0036$, paired $t$ test; no substantial change in fluorescence was found in proximal pyramidal cell dendrites; Supplementary Fig. 3). We next investigated whether basal OLM ${ }^{\alpha 2}$ cell activity influences entorhinal cortex inputs. We used voltage imaging with an extracellular VSD (RH795) to measure the spread of excitation, defined as the fluorescence change ratio between stratum radiatum and SLM, following temporoammonic pathway stimulation (Fig. 1c). We then compared the spread of excitation in Chrna2-cre mice with mice in which inhibition from OLM ${ }^{\alpha 2}$ cells was removed (by crossing Chrna2-cre mice with mice carrying a loxP-flanked Viaat allele ${ }^{22}$, Viaat ${ }^{\text {loxP/loxP}}$; see Online Methods and Supplementary Fig. 2b). Chrna2-cre; Viaat loxP/loxP mice exhibited a 13.7-fold increase in voltage spread from SLM to stratum radiatum following temporoammonic stimulation (Chrna2-cre; Viaat loxP/loxP, $0.57 \pm 0.06$ of SLM $\Delta F / F_{0}$; Chrna2-cre, $0.04 \pm 0.01 ; n=6, t_{5}=7.03$, $P<0.001, t$ test; Fig. 1c). These data suggest that $\mathrm{OLM}^{\alpha 2}$ cells control the efficacy of entorhinal cortex inputs by targeted inhibition of pyramidal cell distal dendrites.

In addition to inhibiting SLM, a recent study proposed that OLM cells would have an opposite effect in stratum radiatum by inhibiting interneurons that target pyramidal cells at the same dendritic compartments as the Schaffer collateral synapses ${ }^{14}$, thereby disinhibiting CA3 inputs. We tested whether activation of OLM ${ }^{\alpha 2}$ cells can increase the excitatory effect of Schaffer collateral inputs by optogenetically activating $\mathrm{OLM}^{\alpha 2}$ cells while recording electrical activity in pyramidal cell dendrites using an extracellular VSD (DI-4-ANBDQPQ) ${ }^{23}$. Of note, this red-shifted VSD was designed to have a different excitation spectrum from channelrhodopsin (ChR) activation ${ }^{23}$. ChR expression in OLM cells was achieved by transducing OLM ${ }^{\alpha 2}$ cells of Chrna2-cre mice with a Cre-activated ChR2 variant, H134R (hChR2), using adeno-associated viral vectors ${ }^{24}$. Viral production of hChR2 was restricted to $\mathrm{OLM}^{\alpha 2}$ cells expressing Cre by using the loxP-flanked/ inverse hChR2 frame strategy, as well as anatomically restricting the injection of the virus to CA1 (Supplementary Fig. $4 \mathbf{a}-\mathbf{c}$ ). In addition, light pulses were limited to stratum oriens by using a beveled optical fiber positioned $\sim 2 \mathrm{~mm}$ above the slice surface. Current-clamp recordings showed that $400-\mathrm{ms}$ blue $(473 \mathrm{~nm})$ light pulses triggered
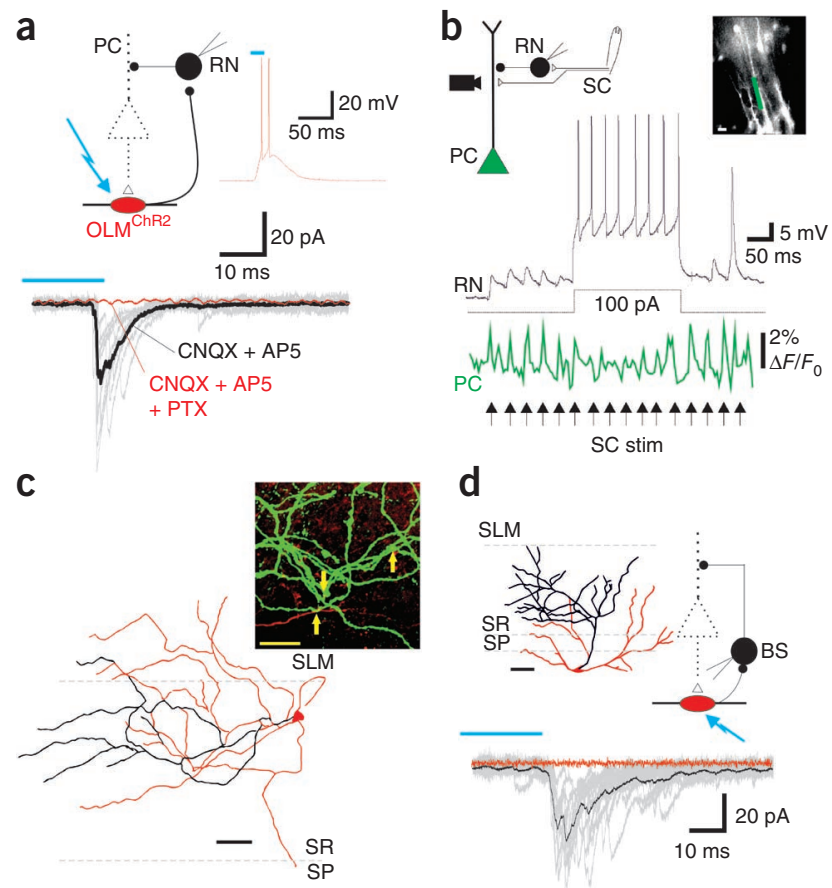

d

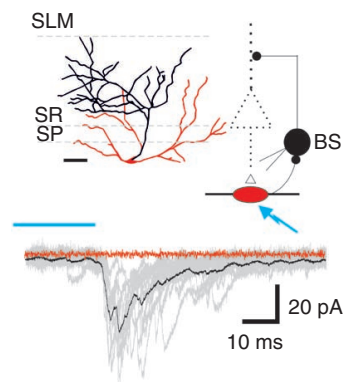

action potentials in ChR2-expressing OLM ${ }^{\alpha 2}\left(\mathrm{OLM}^{\mathrm{ChR} 2}\right)$ cells at frequencies that were directly dependent on light intensity. For example, in current-clamp recordings, $1.4 \mathrm{~mW}$ of laser power (at the tip of the fiber) generated $0.7 \pm 0.5$ action potentials per pulse, whereas $4.7-\mathrm{mW}$ pulses triggered $8.2 \pm 1.0$ action potentials per pulse (Supplementary Fig. 4d,e). Longer 1.4-mW laser pulses ( $5 \mathrm{~min}$ ) produced a moderate firing rate adaptation in $\mathrm{OLM}^{\mathrm{ChR} 2}$ cells (cell-attached recordings; mean action potential frequency: $4.3 \pm 1.0 \mathrm{~Hz}$ without light, $8.4 \pm$ $0.7 \mathrm{~Hz}$ and $6.3 \pm 0.9 \mathrm{~Hz}$ during the first and fifth minutes following light onset, respectively; $P<0.001$ when comparing the first and fifth minutes, paired $t$ test, $t_{9}=5.03, n=10$; Supplementary Fig. 4f).

By using the red-shifted VSD, we found that light activation of $\mathrm{OLM}^{\mathrm{ChR} 2}$ cells strongly suppressed the response to temporoammonic pathway stimulation (control, 8.7 $\pm 1.4 \Delta F / F_{0} \mathrm{~s}$; light, $3.0 \pm 1.1 \Delta F / F_{0} \mathrm{~s}$; $P=0.006$, paired $t$ test, $t_{4}=5.28, n=5$; Supplementary Fig. 5). On the other hand, stimulation of the Schaffer collateral pathway led to a stronger depolarization in stratum radiatum when OLM ${ }^{\mathrm{ChR} 2}$ cells were firing (control, $1.3 \pm 1.1 \Delta F / F_{0} \mathrm{~s}$; light, $4.5 \pm 0.4 \Delta F / F_{0} \mathrm{~s} ; P=0.05$, paired $t$ test, $t_{4}=2.69, n=5$; Fig. 1d), consistent with a disinhibitory role of OLM cells ${ }^{14}$. To confirm this, we patched apical dendrites of pyramidal cell in stratum radiatum while stimulating Schaffer collateral inputs, holding the membrane potential at $-60 \mathrm{mV}$ (close to the $\mathrm{Cl}^{-}$reversal potential of our recording solution). Consistent with VSD data, dendritic voltage clamp recording (in the presence of D-(-)-2-amino-5-phosphonopentanoic acid (AP5) to avoid dendritic spikes) revealed that light activation of $\mathrm{OLM}^{\mathrm{ChR} 2}$ cells leads to larger excitatory postsynaptic currents (EPSCs) summation in dendrites of pyramidal cells in stratum radiatum (measured as the area under the curve of AMPA EPSC produced by 11 Schaffer collateral stimulation pulses at $20 \mathrm{~Hz}$; light off, $1.7 \pm 0.3 \mathrm{pA}$ s; light on, $2.2 \pm 0.2 \mathrm{pA} \mathrm{s}$; $P=0.02$, paired $t$ test, $t_{4}=3.60, n=5$; Fig. 1e).

It has been shown that Schaffer collateral excitation leads to feedforward inhibition onto pyramidal cells ${ }^{25,26}$. Schaffer collateralassociated stratum radiatum interneurons are strong candidates for providing feedforward inhibition to pyramidal cells ${ }^{25}$. We next tested whether OLM ${ }^{\alpha 2}$ cell-stratum radiatum interneuron connections exist. 
Figure $3 \mathrm{OLM}^{\alpha 2}$ cells suppress LTP in the temporoammonic pathway. Potentiation of temporoammonic synapses after wTBS in hippocampal slices of animals transduced with hChR2 (Chrna2-cre and Chrna2-cre; Viaat ${ }^{\text {oxP/loxP }}$ mice with Cre recombinase-induced expression of ChR2) in control conditions (no light) and when a light pulse was applied 5 min before and during temporoammonic wTBS (see Online Methods). Top traces show field EPSPs (fEPSPs) before (black line), and $10 \mathrm{~min}$ (green line) and 30 min (red line) after wTBS (normalized to the peak amplitude). Bar graphs show the mean normalized slope 30 min after wTBS $\left({ }^{*} P<0.05\right)$. Error bars denote \pm s.e.m. Schematic shows overview of stimulation setup.

Light stimulation of OLM ${ }^{\mathrm{ChR} 2}$ cells elicited inhibitory postsynaptic currents (IPSCs) in six of six stratum radiatum interneurons $(31.5 \pm$ $0.7 \mathrm{pA}$ ), which could be blocked by picrotoxin (PTX; Fig. 2a). The feedforward classification of these stratum radiatum interneurons was subsequently confirmed by the presence of monosynaptic excitatory postsynaptic potentials (EPSPs) induced by Schaffer collateral stimulation and the inhibition of pyramidal cell dendrites following their activation. Schaffer collateral stimulation produced EPSPs of $7.5 \pm 0.3 \mathrm{mV}$ in stratum radiatum interneurons, with a delay (pulse time to $10 \%$ EPSP amplitude) of $1.6 \pm 0.04 \mathrm{~ms}$ ( $n=6$ cells; Fig. 2 b). To visualize the effect of stratum radiatum interneuron synapses on pyramidal cell dendrites, we developed an electroporation technique to fill pyramidal cell dendrites with VSD. We found that pulses of Schaffer collateral stimulation induced phasic depolarization of pyramidal cell dendrites, which were significantly lowered by the spiking of a single stratum radiatum interneuron (from $1.7 \pm 0.2 \Delta F / F_{0}$ to $1.2 \pm 0.2 \Delta F / F_{0}$, $P=0.01$, paired $t$ test, $t_{5}=3.84, n=6$; Fig. $2 \mathbf{b}$ ). Reconstruction of these interneurons showed cell bodies near the border of stratum radiatum and SLM, with axonal arborizations predominantly confined to stratum
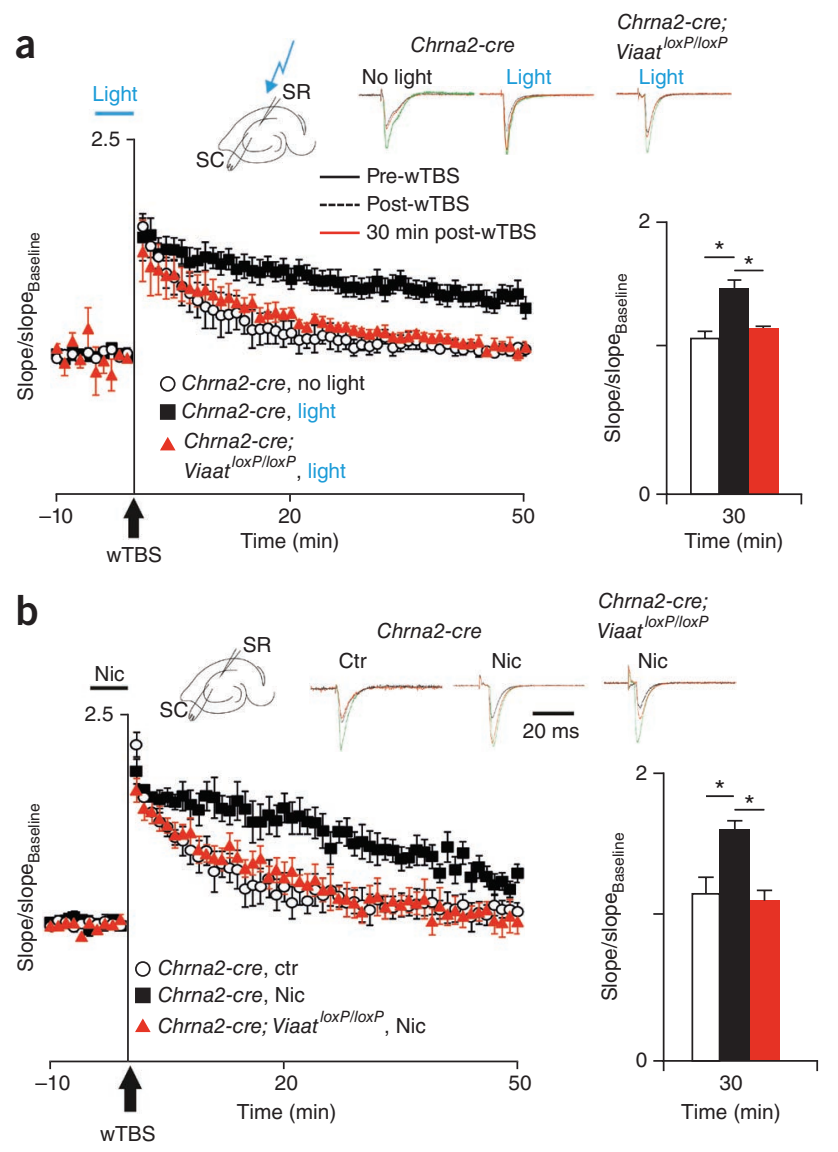

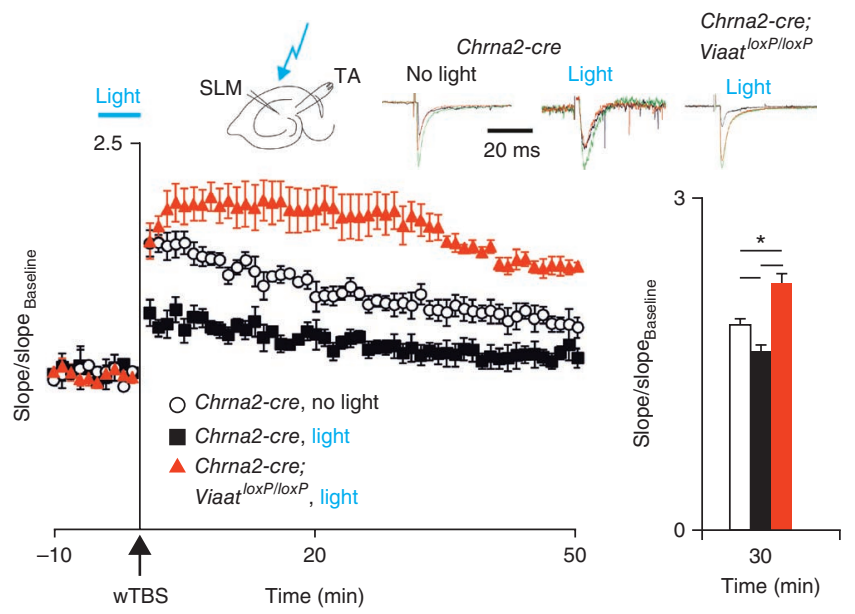

radiatum (Fig. 2c). Consistent with electrophysiological data (Fig. 2a), confocal images revealed close proximity between OLM $^{\alpha 2}$ cell axons and stratum radiatum interneuron dendrites (Fig. 2c). In addition to Schaffer collateral-associated stratum radiatum interneurons, we also found connections from OLM ${ }^{\mathrm{ChR} 2}$ cells to 7 of 16 bistratified cells (that is, interneurons with axons targeting pyramidal cell dendrites in stratum radiatum ${ }^{27}$; mean IPSC, $48.1 \pm 6.8$ pA; Fig. 2d). Thus, OLM ${ }^{\alpha 2}$ cells are likely to increase pyramidal cell electrogenesis following Schaffer collateral stimulation through disinhibition of proximal pyramidal cell dendrites. Together, our results indicate that $\mathrm{OLM}^{\alpha 2}$ cells may differentially control synaptic efficacy of entorhinal cortex and CA 3 inputs onto CA1; when active, OLM ${ }^{\alpha 2}$ cells inhibit temporoammonic inputs while concomitantly favoring Schaffer collateral synapses.

\section{OLM $^{\alpha 2}$ cells modulate synaptic plasticity in CA1}

The dual role of OLM ${ }^{\alpha 2}$ cells in proximal and distal pyramidal cell dendritic compartments could differentially affect plasticity in the Schaffer collateral-CA1 and temporoammonic-CA1 pathways. We examined the effect of OLM ${ }^{\alpha 2}$ cells on synaptic potentiation induced by the weak theta burst stimulation (wTBS) protocol. We found that light activation of OLM ${ }^{\mathrm{ChR} 2}$ cells (1.4-mW laser power) for a 5-min period before and during temporoammonic wTBS largely attenuated the induction of synaptic potentiation in the temporoammonic-CA1 pathway $(P=0.04$ at $t=30 \mathrm{~min}$ after wTBS, $t$ test, $t_{6}=2.59, n=4$ per group; Fig. 3$)$. We then performed this experiment in Chrna2-cre; Viaat loxP/loxP mice. Notably, OLM ${ }^{\text {ChR2 }}$ cells in Chrna2-cre; Viaat loxP/loxP mice showed no substantial difference in firing properties and response to light in comparison to cells from Chrna2-cre mice (Supplementary Fig. 4a-e). We found that temporoammonic-CA1 potentiation was highly facilitated in Chrna2-cre; Viaat loxP/loxP mice transduced with hChR2 independently of light activation $(P=0.01$ at $t=30 \mathrm{~min}$ after wTBS, $t$ test, $t_{6}=3.39, n=4$ per group; Fig. 3 and Supplementary Fig. 6).

Figure $4 \mathrm{OLM}^{\alpha 2}$ cells enhance LTP in the Schaffer collateral pathway. (a) Potentiation of Schaffer collateral synapses in Chrna2-cre and Chrna2-cre; Viaat ${ }^{\text {oxP/IoxP }}$ mice with Cre recombinase-induced expression of ChR2 in control conditions (no light) and with a light pulse applied 5 min before and during Schaffer collateral wTBS. Top traces show normalized fEPSPs before (black line), and $10 \mathrm{~min}$ (green line) and $30 \mathrm{~min}$ (red line) after wTBS. Bar graphs show the mean normalized slope 30 min after wTBS. Error bars denote \pm s.e.m. ${ }^{*} P<0.05$. (b) Data are presented as in a, but with $1 \mu \mathrm{M}$ bath-applied nicotine (Nic) instead of light stimulation. Schematics show overview of stimulation setup. 
Thus, our results indicate that $\mathrm{OLM}^{\alpha 2}$ cell activation inhibits potentiation of the temporoammonic-CA1 pathway.

OLM cells could also modulate the plasticity of Schaffer collateral inputs by the disinhibitory mechanism described above (see also ref. 14). This hypothesis was tested by applying wTBS in Schaffer collateral before and after light activation of OLM ${ }^{\mathrm{ChR} 2}$ cells. We found that light activation was necessary to facilitate $\operatorname{LTP}(P=0.004$ at $t=30 \mathrm{~min}$, $t$ test, $t_{7}=4.17, n=4-5$ per group), whereas Schaffer collateral wTBS alone was insufficient to produce LTP (Fig. 4a). Light activation of $\mathrm{OLM}^{\mathrm{ChR} 2}$ cells in Chrna2-cre; Viaat loxP/loxP animals had no effect on Schaffer collateral-CA1 LTP (Fig. 4a and Supplementary Fig. 7a). Notably, wTBS of Schaffer collateral inputs elicits LTP if nicotine is present in the perfusate ${ }^{14}$. OLM cells are likely to mediate the facilitation of LTP induction by nicotine as a result of their particular sensitivity to nicotine ${ }^{28}$. Consistent with previous findings ${ }^{14}$, wTBS in the presence of nicotine induced LTP in the Schaffer collateral-CA1 synapse $\left(P=0.017\right.$ at $t=30 \mathrm{~min}$ after wTBS, $t$ test, $t_{9}=2.92, n=5-6$ per group; Fig. $4 \mathbf{b}$ and Supplementary Fig. $7 \mathbf{b})$. However, this effect was absent in Chrna2-cre; Viaat loxP/loxP mice (Fig. $4 \mathbf{b}$ and Supplementary Fig. 7b), suggesting that VIAAT-mediated inhibition from OLM ${ }^{\alpha 2}$ cells is required for the effect of nicotine on LTP. Notably, currentclamp recordings revealed that $\mathrm{OLM}^{\alpha 2}$ neurons responded similarly to Schaffer collateral stimulation during nicotine or light application ( $n=11$; Supplementary Fig. 7c,d). Thus, our results indicate that $\mathrm{OLM}^{\alpha 2}$ cells strongly facilitate LTP in the Schaffer collateral-CA1 pathway and suppress LTP in the temporoammonic-CA1 pathway.

\section{OLM ${ }^{\alpha 2}$ cells receive direct cholinergic inputs}

We next sought to determine potential network mechanisms that could indirectly modulate CA3 and entorhinal cortex inputs by controlling the activity of CA1 OLM cells. Consistent with previous findings ${ }^{29}$, local pyramidal cell depolarization produced EPSCs (recorded at $-60 \mathrm{mV}$ ) in $\mathrm{OLM}^{\alpha 2}$ cells (mean amplitude $=-109.3 \pm 8.7 \mathrm{pA}$, $n=8$ of 15 pairs). In addition, spikes in bistratified or trilaminar interneurons in CA1 stratum oriens elicited IPSCs in OLM ${ }^{\alpha 2}$ cells with an average magnitude of $67.6 \pm 7.8 \mathrm{pA}$ ( $n=7$ of 25 pairs). A previous study found that gap junctions exist among $\mathrm{SOM}^{+}$cells ${ }^{30}$. Consistent with this, paired recordings of OLM ${ }^{\alpha 2}$ cells in Chrna2-cre; $226^{\text {tom }}$ mice with applied presynaptic voltage steps ranging from -80 to $0 \mathrm{mV}$ produced outward currents in the presynaptic cell and inward currents postsynaptically ( $n=4$ of 21 pairs). The mean junctional conductance calculated by $g=-I_{\text {Post }} /\left(V_{\text {Pre }}-V_{\text {Post }}\right)$ (ref. 31) was equal to $0.7 \pm 0.1 \mathrm{nS}$ (Supplementary Fig. 8) and the coupling coefficient was $0.13 \pm 0.03\left(n=4\right.$, measured in the cell with the lowest $\left.R_{\mathrm{M}}\right)$. These findings indicate that $\mathrm{OLM}^{\alpha 2}$ cells receive both local excitation and inhibition and are connected by gap junctions.

We next assessed extrahippocampal inputs to OLM ${ }^{\alpha 2}$ cells by stimulating the temporoammonic and fimbria fornix pathways. Temporoammonic stimulation did not produce synaptic activity in OLM ${ }^{\alpha 2}$ cells $(n=21)$. In contrast, fimbria fornix stimulation generated synaptic currents in 5 of 23 cells in CA1 (but not in the subiculum, $n=0$ of 17 ) with average amplitude of $-46.3 \pm 5.4 \mathrm{pA}$. EPSC decay time constants could be fit with a double exponential function (fast and slow time constants $=2.4 \pm 0.3$ and $12.7 \pm 2.6 \mathrm{~ms}$ ). The EPSCs were resistant to the AMPA receptor blocker 6-cyano7-nitroquinoxaline-2,3-dione (CNQX), the NMDA receptor blocker AP5 and the GABA receptor blocker PTX (Fig. 5a). Application of the CHRNA7 blocker methyllycaconitine citrate (MLA) lowered the EPSC amplitude to $-12.5 \pm 2.7 \mathrm{pA}\left(P=0.01\right.$, paired $t$ test, $t_{4}=4.24$, $n=5$; Fig. 5a), whereas a subsequent application of the nonspecific nicotinic receptor antagonist mecamylamine hydrochloride (MEC) a

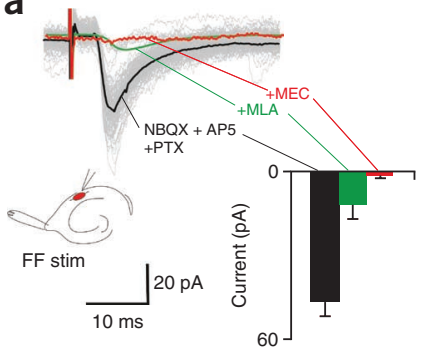

b

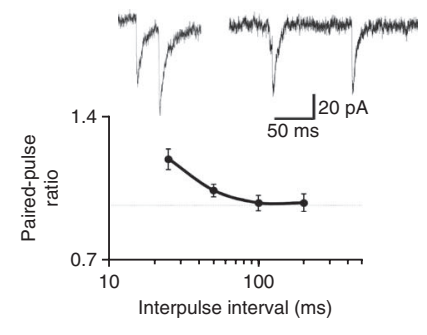

Figure $5 \mathrm{OLM}^{\alpha 2}$ cells receive remote cholinergic input. (a) Cholinergic EPSCs elicited by fimbria fornix (FF) stimulation (gray, isolated by the application of glutamate and GABA receptor blockers; the black trace shows the average EPSC). The average EPSCs after the addition of the $\alpha 7$-blocker MLA (green trace) and the nicotine blocker MEC (red trace) are also shown. Peak EPSC amplitudes are shown in the right bar graph. Error bars denote \pm s.e.m. Schematic shows overview of stimulation setup. (b) Average paired-pulse ratio of fimbria fornix-induced cholinergic EPSC in OLM ${ }^{\alpha 2}$ cells as a function of the interpulse interval. Error bars denote \pm s.e.m. The top traces show examples of 25-ms (left) and 100-ms (right) interpulse intervals.

blocked the remaining current. Paired-pulse stimulation of the fimbria fornix resulted in a moderate facilitation of EPSCs in OLM ${ }^{\alpha 2}$ cells (paired-pulse ratio of $1.19 \pm 0.05$ for a 25 -ms interpulse interval and $0.98 \pm 0.04$ for a 200-ms interval, $P=0.02$, paired $t$ test, $t_{4}=3.54$, $n=5$; Fig. 5b). Fibers arising from the MS-DBB, traveling through the fimbria fornix, terminate in CA1 stratum oriens ${ }^{32}$. However, the neurotransmitters involved and the cellular targets of these inputs have not been characterized. Our results suggest that EPSCs in OLM ${ }^{\alpha 2}$ cells evoked by fimbria fornix stimulation are mediated by ionotropic cholinergic receptors, with an important contribution from the $\alpha 7$ subunit. Taken together, our data indicate that cholinergic projections from the MS-DBB can directly excite OLM cells. This effect is modulated by local excitation and inhibition and is likely to be amplified by gap junctions.

\section{DISCUSSION}

OLM cells constitute a large GABAergic interneuron population in the hippocampus, but their network function remains poorly understood. We found that OLM cells in CA1 are characterized by the expression of Chrna2. A Chrna2-cre mouse line allowed us to identify and control OLM cells. We found that OLM cells inhibited pyramidal cell dendritic compartments localized at SLM, reducing the strength of the direct input from entorhinal cortex layer III. In addition, we observed that OLM cells inhibited stratum radiatum interneurons that synapse on proximal pyramidal cell dendritic compartments, suggesting that OLM cells counteract Schaffer collateral feedforward inhibition. Moreover, we found that OLM cells suppressed LTP in the temporoammonic-CA1 pathway while facilitating LTP in the Schaffer collateral-CA1 pathway. Together, our findings suggest that OLM interneurons can control the information flow into CA1 pyramidal cells by modulating direct sensory inputs from entorhinal cortex and internal inputs originating from CA3 (Supplementary Fig. 9).

Chrna2 is, to the best of our knowledge, the most specific marker of a morphologically well-defined hippocampal interneuron population to date. Other markers, such as PV, are shared by different classes of interneurons ${ }^{5,33}$; in particular, SOM, an often used marker for OLM cells, is also expressed by other interneuron types, such as bistratified and hilar perforant path-associated cells ${ }^{5,34}$. Furthermore, $\mathrm{SOM}$ is expressed by interneurons in all hippocampal subregions, 
whereas Chrna2 expression is restricted to CA1 and subiculum (Supplementary Fig. 1). Nevertheless, the generation of Pvalb-cre and Som-cre mouse lines ${ }^{35}$ has been a major advance for the study of interneuron function in oscillatory activity and behavior ${ }^{3,4,36,37}$; more selective markers, such as the one described here, should allow the study of the specific cell types in the larger population of $\mathrm{PV}^{+}$ and $\mathrm{SOM}^{+}$cells.

Using extra- and intracellular voltage dye imaging, we found that OLM cells inhibited distal pyramidal cell dendrites at SLM, as expected from anatomical data (Fig. 1 and Supplementary Fig. 1). Less trivial, voltage imaging of stratum radiatum and dendritic patch-clamp recordings revealed that OLM cells disinhibited proximal pyramidal cell dendrites. This result suggests a connection between OLM cells and dendritic inhibiting CA1 interneurons. This connection was confirmed by optogenetic stimulation of OLM cells, which led to IPSCs in two types of dendritic inhibiting interneurons: bistratified cells in stratum oriens and Schaffer collateral-associated interneurons in stratum radiatum near the border of SLM. These connections likely account for the enhanced depolarization produced by Schaffer collateral stimulation when OLM cells are active. In contrast, a recent study showed that the removal of inhibition arising from $\mathrm{SOM}^{+}$neurons increases the amplitude of Schaffer collateral EPSPs ${ }^{38}$. However, as SOM is not a specific marker of OLM cells, this effect could derive from decreased inhibition from other interneuron subtypes, such as bistratified cells or other dendritic targeting interneurons that are supplied with Schaffer collateral inputs ${ }^{39}$. In addition, given that the pyramidal cell dendrite is notoriously active ${ }^{40}$, EPSCs sourced at the proximal pyramidal cell dendrite could generate dendritic spikes in SLM. In this scenario, decreased inhibition from $\mathrm{SOM}^{+}$interneurons could increase the net effect of Schaffer collateral stimulation by increasing tonic excitation and the generation of dendritic spikes.

How might OLM cells be controlled? It has previously been shown that OLM cells receive local excitation ${ }^{29}$ and inhibition ${ }^{38}$. We found that stimulation of the fimbria fornix elicited cholinergic EPSCs in CA1 OLM ${ }^{\alpha 2}$ cells. The fimbria fornix carries fibers originating from the MS-DBB, the main subcortical source of acetylcholine to the hippocampus ${ }^{41}$; thus, these results suggest a direct connection between cholinergic neurons in the MS-DBB and OLM ${ }^{\alpha 2}$ cells in CA1. We hypothesize that acetylcholine acting on OLM ${ }^{\alpha 2}$ cells could gate the information flow in CA1 by favoring the decoding of information stored in CA3 via the Schaffer collateral-CA1 synapse while suppressing sensory information from the temporoammonic pathway. It should be noted that OLM cells express other nicotinic receptor subunits apart from Chrna2, such as Chrna7, which seem to be more influential in mediating the cholinergic responses of OLM cells (Fig. 5a). Although we focused on the network properties of OLM cells, using Chrna2 as a marker, the function of Chrna2 in OLM cells should be explored in the future.

It has been previously hypothesized that OLM cells mediate LTP facilitation by nicotine ${ }^{14}$. We found that optogenetic activation of $\mathrm{OLM}^{\alpha 2}$ cells facilitate Schaffer collateral-CA1 LTP after wTBS in a manner similar to nicotine application. Conversely, nicotine had no effect on LTP in animals in which VIAAT-mediated transmission was specifically removed from OLM ${ }^{\alpha 2}$ cells (Fig. 4). These results suggest that OLM ${ }^{\alpha 2}$ cells account for the effect of nicotine on synaptic plasticity and that OLM ${ }^{\alpha 2}$ cells have a pivotal role in mediating the memory enhancing effects of nicotine observed in vivo ${ }^{42}$. LTP in the temporoammonic-CA1 pathway, on the other hand, was suppressed by optogenetic stimulation of OLM ${ }^{\alpha 2}$ cells (Fig. 3), whereas the selective removal of GABAergic transmission from OLM ${ }^{\alpha 2}$ cells enhanced LTP induction in this pathway (Fig. 3). It should be cautioned, however, that the hippocampal network of Chrna2-cre; Viaat loxP/loxP mice may harbor potential compensatory changes. In any event, the results indicate that $\mathrm{OLM}^{\alpha 2}$ cells provide inhibitory control over direct entorhinal cortex inputs. Thus, a greater influence of entorhinal cortex inputs over CA1 pyramidal cells could be achieved by turning off the background activity of OLM cells. It is important to note that, although OLM cells fire tonically around theta frequency in slices ${ }^{11}$ (Supplementary Fig. 4f), it remains to be established whether OLM cells can also be tonically activated by neuromodulators in vivo.

The opposite effects of OLM ${ }^{\alpha 2}$ cells on Schaffer collateral-CA1 and temporoammonic-CA1 plasticity is likely explained by a local modulation of intracellular $\mathrm{Ca}^{2+}$ levels in different pyramidal cell dendritic compartments. $\mathrm{Ca}^{2+}$ is one of the main signals for the induction of LTP and LTD ${ }^{43}$, and a direct inhibition of pyramidal cells at the distal dendrites would likely lower $\mathrm{Ca}^{2+}$ concentration by closing voltage-gated $\mathrm{Ca}^{2+}$ channels, whereas a disinhibition of the proximal dendrites increases $\mathrm{Ca}^{2+}$ levels by the opposite mechanism ${ }^{43}$.

In summary, we found that hippocampal Chrna2 is specifically expressed in OLM cells of the CA1 region and subiculum, which we then used to examine their role in regulating synaptic plasticity of the hippocampal microcircuitry. Given that OLM cell dysfunction has been linked to epilepsy ${ }^{44}$, schizophrenia ${ }^{45}$ and cognitive impairment ${ }^{46}$, manipulations of hippocampal CHRNA2 can potentially be used as a target for therapeutic strategies.

\section{METHODS}

Methods and any associated references are available in the online version of the paper.

Note: Supplementary information is available in the online version of the paper.

\section{ACKNOWLEDGMENTS}

We thank G. Buzsaki, P. Ascher, B. Lamotte d'Incamps, O. Amaral and E. Hanse for comments on earlier versions of this manuscript. This work was supported by the foundations of Märta och Kjell Beijer, Hållsten and Göran Gustafsson, The Swedish Foundation for International Cooperation in Research and Higher Education, the Brazilian Federal Agency for Support and Evaluation of Graduate Education, the Brazilian National Council of Technological and Scientific Development, the Research Support Agency of the State of Rio Grande do Norte, US National Institutes of Health grant R01EB001963, the Swedish Medical Research Council, the Swedish Brain Foundation, and Uppsala University. K.K. is a Royal Swedish Academy of Sciences Research Fellow supported by a grant from the Knut and Alice Wallenberg Foundation.

\section{AUTHOR CONTRIBUTIONS}

H.G., A. Enjin and K.K. designed and produced the transgenic mice. R.N.L., K.E.L., A.B.L.T., L.M.L. and K.K. designed the experiments. R.N.L., K.E.L., S.M., H.M., K.P. and A. Eriksson performed the experiments. R.N.L., K.E.L., A.B.L.T. and K.K. analyzed data and wrote the paper.

\section{COMPETING FINANCIAL INTERESTS}

The authors declare no competing financial interests.

Published online at http://www.nature.com/doifinder/10.1038/nn.3235.

Reprints and permissions information is available online at http://www.nature.com/ reprints/index.html.

1. Morris, R.G., Garrud, P., Rawlins, J.N. \& O'Keefe, J. Place navigation impaired in rats with hippocampal lesions. Nature 297, 681-683 (1982).

2. Eichenbaum, H. Hippocampus: cognitive processes and neural representations that underlie declarative memory. Neuron 44, 109-120 (2004).

3. Murray, A.J. et al. Parvalbumin-positive CA1 interneurons are required for spatial working, but not for reference memory. Nat. Neurosci. 14, 297-299 (2011).

4. Korotkova, T., Fuchs, E.C., Ponomarenko, A., von Engelhardt, J. \& Monyer, H. NMDA receptor ablation on parvalbumin-positive interneurons impairs hippocampal synchrony, spatial representations and working memory. Neuron 68, 557-569 (2010).

5. Freund, T.F. \& Buzsaki, G. Interneurons of the hippocampus. Hippocampus 6 , 347-470 (1996). 
6. Somogyi, P. \& Klausberger, T. Defined types of cortical interneurone structure space and spike timing in the hippocampus. J. Physiol. (Lond.) 562, 9-26 (2005).

7. Ascoli, G.A. et al. Petilla terminology: nomenclature of features of GABAergic interneurons of the cerebral cortex. Nat. Rev. Neurosci. 9, 557-568 (2008).

8. Gradinaru, V. et al. Molecular and cellular approaches for diversifying and extending optogenetics. Cell 141, 154-165 (2010).

9. Maccaferri, G. \& McBain, C.J. Passive propagation of LTD to stratum oriens-alveus inhibitory neurons modulates the temporoammonic input to the hippocampal CA1 region. Neuron 15, 137-145 (1995).

10. Tort, A.B., Rotstein, H.G., Dugladze, T., Gloveli, T. \& Kopell, N.J. On the formation of gamma-coherent cell assemblies by oriens lacunosum-moleculare interneurons in the hippocampus. Proc. Natl. Acad. Sci. USA 104, 13490-13495 (2007).

11. Gloveli, T. et al. Orthogonal arrangement of rhythm-generating microcircuits in the hippocampus. Proc. Natl. Acad. Sci. USA 102, 13295-13300 (2005).

12. Rotstein, H.G. et al. Slow and fast inhibition and an H-current interact to create a theta rhythm in a model of CA1 interneuron network. J. Neurophysiol. 94, 1509-1518 (2005).

13. Wulff, P. et al. Hippocampal theta rhythm and its coupling with gamma oscillations require fast inhibition onto parvalbumin-positive interneurons. Proc. Natl. Acad. Sci. USA 106, 3561-3566 (2009).

14. Nakauchi, S., Brennan, R.J., Boulter, J. \& Sumikawa, K. Nicotine gates long-term potentiation in the hippocampal CA1 region via the activation of alpha2* nicotinic ACh receptors. Eur. J. Neurosci. 25, 2666-2681 (2007).

15. Cutsuridis, V., Cobb, S. \& Graham, B.P. Encoding and retrieval in a model of the hippocampal CA1 microcircuit. Hippocampus 20, 423-446 (2010).

16. Hasselmo, M.E. Neuromodulation: acetylcholine and memory consolidation. Trends Cogn. Sci. 3, 351-359 (1999).

17. Ishii, K., Wong, J.K. \& Sumikawa, K. Comparison of alpha2 nicotinic acetylcholine receptor subunit mRNA expression in the central nervous system of rats and mice. J. Comp. Neurol. 493, 241-260 (2005)

18. Jia, Y., Yamazaki, Y., Nakauchi, S. \& Sumikawa, K. Alpha2 nicotine receptors function as a molecular switch to continuously excite a subset of interneurons in rat hippocampal circuits. Eur. J. Neurosci. 29, 1588-1603 (2009).

19. Jia, Y., Yamazaki, Y., Nakauchi, S., Ito, K. \& Sumikawa, K. Nicotine facilitates long-term potentiation induction in oriens-lacunosum moleculare cells via $\mathrm{Ca}^{2+}$ entry through non-alpha7 nicotinic acetylcholine receptors. Eur. J. Neurosci. 31, 463-476 (2010).

20. Maccaferri, G. \& McBain, C.J. The hyperpolarization-activated current (Ih) and its contribution to pacemaker activity in rat CA1 hippocampal stratum oriens-alveus interneurones. J. Physiol. (Lond.) 497, 119-130 (1996).

21. Palmer, L.M. \& Stuart, G.J. Site of action potential initiation in layer 5 pyramidal neurons. J. Neurosci. 26, 1854-1863 (2006).

22. Tong, Q., Ye, C.-P., Jones, J.E., Elmquist, J.K. \& Lowell, B.B. Synaptic release of GABA by AgRP neurons is required for normal regulation of energy balance. Nat. Neurosci. 11, 998-1000 (2008)

23. Kee, M.Z., Wuskell, J.P., Loew, L.M., Augustine, G.J. \& Sekino, Y. Imaging activity of neuronal populations with new long-wavelength voltage-sensitive dyes. Brain Cell Biol. 36, 157-172 (2008).

24. Cardin, J.A. et al. Targeted optogenetic stimulation and recording of neurons in vivo using cell type-specific expression of Channelrhodopsin-2. Nat. Protoc. 5, 247-254 (2010).

25. Maccaferri, G. \& Dingledine, R. Control of feedforward dendritic inhibition by NMDA receptor-dependent spike timing in hippocampal interneurons. J. Neurosci. 22, 5462-5472 (2002).
26. Pouille, F. \& Scanziani, M. Enforcement of temporal fidelity in pyramidal cells by somatic feed-forward inhibition. Science 293, 1159-1163 (2001).

27. Maccaferri, G., Roberts, J.D., Szucs, P., Cottingham, C.A. \& Somogyi, P. Cell surface domain specific postsynaptic currents evoked by identified GABAergic neurones in rat hippocampus in vitro. J. Physiol. (Lond.) 524, 91-116 (2000).

28. Tu, B., Gu, Z., Shen, J.X., Lamb, P.W. \& Yakel, J.L. Characterization of a nicotine-sensitive neuronal population in rat entorhinal cortex. J. Neurosci. 29, 10436-10448 (2009).

29. Blasco-Ibáñez, J.M. \& Freund, T.F. Synaptic input of horizontal interneurons in stratum oriens of the hippocampal CA1 subfield: structural basis of feed-back activation. Eur. J. Neurosci. 7, 2170-2180 (1995).

30. Minneci, F. et al. Signaling properties of stratum oriens interneurons in the hippocampus of transgenic mice expressing EGFP in a subset of somatostatincontaining cells. Hippocampus 17, 538-553 (2007).

31. Veruki, M.L., Oltedal, L. \& Hartveit, E. Electrical coupling and passive membrane properties of All amacrine cells. J. Neurophysiol. 103, 1456-1466 (2010).

32. Gulyás, A.I., Gorcs, T.J. \& Freund, T.F. Innervation of different peptide-containing neurons in the hippocampus by GABAergic septal afferents. Neuroscience 37, 31-44 (1990).

33. Gulyás, A.l. et al. Parvalbumin-containing fast-spiking basket cells generate the field potential oscillations induced by cholinergic receptor activation in the hippocampus. J. Neurosci. 30, 15134-15145 (2010).

34. Klausberger, T. et al. Spike timing of dendrite-targeting bistratified cells during hippocampal network oscillations in vivo. Nat. Neurosci. 7, 41-47 (2004).

35. Taniguchi, H. et al. A resource of Cre driver lines for genetic targeting of GABAergic neurons in cerebral cortex. Neuron 71, 995-1013 (2011).

36. Fuchs, E.C. et al. Recruitment of parvalbumin-positive interneurons determines hippocampal function and associated behavior. Neuron 53, 591-604 (2007)

37. Cardin, J.A. et al. Driving fast-spiking cells induces gamma rhythm and controls sensory responses. Nature 459, 663-667 (2009).

38. Lovett-Barron, M. et al. Regulation of neuronal input transformations by tunable dendritic inhibition. Nat. Neurosci. 15, 423-430 (2012).

39. Elfant, D., Pál, B.Z., Emptage, N. \& Capogna, M. Specific inhibitory synapses shift the balance from feedforward to feedback inhibition of hippocampal CA1 pyramidal cells. Eur. J. Neurosci. 27, 104-113 (2008).

40. Kim, S., Guzman, S.J., Hu, H. \& Jonas, P. Active dendrites support efficient initiation of dendritic spikes in hippocampal CA3 pyramidal neurons. Nat. Neurosci. 15, 600-606 (2012).

41. Colom, L.V. Septal networks: relevance to theta rhythm, epilepsy and Alzheimer's disease. J. Neurochem. 96, 609-623 (2006).

42. Davis, J.A. \& Gould, T.J. Associative learning, the hippocampus, and nicotine addiction. Curr. Drug Abuse Rev. 1, 9-19 (2008).

43. Lynch, M.A. Long-term potentiation and memory. Physiol. Rev. 84, 87-136 (2004).

44. Dugladze, T. et al. Impaired hippocampal rhythmogenesis in a mouse model of mesial temporal lobe epilepsy. Proc. Natl. Acad. Sci. USA 104, 17530-17535 (2007).

45. Neymotin, S.A. et al. Ketamine disrupts theta modulation of gamma in a computer model of hippocampus. J. Neurosci. 31, 11733-11743 (2011).

46. Stanley, E.M., Fadel, J.R. \& Mott, D.D. Interneuron loss reduces dendritic inhibition and GABA release in hippocampus of aged rats. Neurobiol. Aging 33, 431 e1-13 (2012).

47. Franklin, K.B.J. \& Paxinos, G. The Mouse Brain in Stereotaxic Coordinates 3rd edn. (Elsevier, 2007). 


\section{ONLINE METHODS}

Mice. Chrna2-cre transgenic C57BL6 mice were generated by introducing the cre gene at the ATG site of the first coding exon (middle of exon 2) of the Chrna2 gene in a Bacterial Artificial Chromosome (BAC, RP23-48P22). The protocols used and information on the bacterial strain (EL250) are available at http://ncifrederick.cancer.gov/research/brb/recombineeringInformation. aspx. A plasmid containing nls-Cre-SV40 polyA-FRT-Kan/Neo-FRT was generated as a PCR template (information on request). Successful introduction of the Cre construct into the BAC was confirmed with PCR using the primers GACAGCCATTTTCTCGCTTC and AGGCAAATTTTGGTGTACG in a standard PCR reaction; the same primers were subsequently used for genotyping of the mice. BAC plasmid length was analyzed by enzyme restriction $\left(2 \mathrm{~h}, 37^{\circ} \mathrm{C}\right)$, followed by Pulse Field Gel Electrophoresis (PFGE, CHEF mapper, Bio-Rad) $6 \mathrm{~V} \mathrm{~h}^{-1}, 18 \mathrm{~h}, 120^{\circ}$ switch, 1-20-s switch time. Validation sequencing of the $\mathrm{BAC}$ construct was made with custom-designed primers covering the modified region (MWG-Biotech AG). The modified BAC was linearized by NotI and purified as described previously ${ }^{48}$. Briefly, the BAC DNA was separated with PFGE followed by $\beta$-agarase (NEB) digestion and dialysis to exchange the buffer to injection buffer. The modified BAC, which includes $\sim 100 \mathrm{~kb}$ upstream and $\sim 8 \mathrm{~kb}$ downstream of the Chrna2 gene, as well as all introns, was linearized by cleaving with NotI and introduced randomly into the mouse genome by pronuclear injection at Uppsala University Transgenic Facility, which resulted in a founder line with expression of Cre in cells expressing the CHRNA2 protein. Viaat ${ }^{\text {loxP/loxP }}$ mice $^{22}$ and Gt(ROSA)26Sor ${ }^{\text {tm 14(CAG-tdTomato)Hze }}\left(\right.$ R26 $^{\text {tom }}$; Allen Brain Institute) mice have been described elsewhere. All animal procedures were approved by the appropriate local Swedish ethical committee (Uppsala Animal Ethics Committee, Jordbruksverket). Efforts were made to minimize the numbers of animals used.

Electrophysiology. Transverse hippocampal slices were obtained from P21-30 Chrna2-cre; $R 26^{\text {tom }}$ and wild-type littermate mice, Chrna2-cre; Viaat ${ }^{\text {loxP/loxP }}$ mice, and 1-2-month-old hChR2-carrying mice of either sex as previously described and according to the rules of Animal Experimentation of the Uppsala University. Slices were maintained in artificial cerebrospinal fluid (ACSF: 124 $\mathrm{mM} \mathrm{NaCl}, 3.5 \mathrm{mM} \mathrm{KCl}, 1.25 \mathrm{mM} \mathrm{NaH}_{2} \mathrm{PO}_{4}, 1.5 \mathrm{mM} \mathrm{MgCl}_{2}, 1.5 \mathrm{mM} \mathrm{CaCl}_{2}$, $24 \mathrm{mM} \mathrm{NaHCO}_{3}$ and $10 \mathrm{mM}$ glucose), constantly bubbled with $95 \% \mathrm{O}_{2}$ and $5 \% \mathrm{CO}_{2}$. Borosilicate glass electrodes (resistance $=4-8 \mathrm{M} \Omega$ for somatic recordings; $12-18 \mathrm{M} \Omega$ for dendritic recordings) were filled with either potassium gluconate or CsCl-based internal solution ${ }^{49}$. Current- and voltage-clamp recordings were obtained using either a Dagan BVC700 (Dagan), Axopatch 200B or a Multiclamp 700B (Molecular Devices) amplifier; data was acquired by National Instruments DAQ cards and winWCP (J. Dempster, Strathclyde University). No differences between firing and passive membrane properties and morphology of CA1 OLM cells were found between Chrna2-cre and wildtype littermates ( $n=153$ cells); thus, data is presented only from mice carrying Cre recombinase. Postsynaptic currents were obtained in voltage clamp at a holding potential of $-60 \mathrm{mV}$ using a CsCl-based internal solution $\left(\mathrm{Cl}^{-}\right.$reversal potential $=0 \mathrm{mV}$ ).

Extracellular fEPSP recordings (LTP experiments) were obtained by placing a concentric stimulation electrode (FHC) either at stratum radiatum or SLM (for Schaffer collateral or temporoammonic stimulation, respectively) as previously described ${ }^{14}$. A borosilicate glass pipette (4-8 M $\Omega$ ) filled with ACSF was used to record Schaffer collateral or temporoammonic fEPSPs at the CA1 region $200-400 \mu \mathrm{m}$ away from the stimulation electrode. Stimulation strength was adjusted to obtain $50-60 \%$ of the maximum fEPSP amplitude followed by 20 -min recordings ( 200 -ms pulses delivered every $20 \mathrm{~s}$ ) to obtain a stable fEPSP baseline. Stimulus-response curves were obtained from fEPSPs slopes and synaptic potentiation was induced by wTBS (two bursts of four pulses at $100 \mathrm{~Hz}$ spaced by $200 \mathrm{~ms}$ ). The following drugs were bath applied to brain slices: tetrodotoxin $(1 \mu \mathrm{M})$, MLA (Tocris, $10 \mathrm{nM})$, CNQX (Sigma, $10 \mu \mathrm{M})$, AP5 (Sigma, $30 \mu \mathrm{M}$ ), PTX (Sigma, $10 \mu \mathrm{M}$ ), MEC (Sigma, $25 \mu \mathrm{M}$ ) and (-)-nicotine ditartrate (Tocris, $1 \mu \mathrm{M}$ ).

Voltage imaging. We loaded the dye RH795 (Invitrogen) extracellularly by diluting it to $1 \mathrm{mg} \mathrm{ml}^{-1}$ in ACSF and incubating hippocampal slices for 5 min, constantly bubbled with $95 \% \mathrm{O}_{2}$ and $5 \% \mathrm{CO}_{2}$. The red-shifted dye
DI-4-ANBDQPQ ${ }^{23}$ was diluted in absolute ethanol and ejected over the slice under a rapid flow of ACSF. Pyramidal cell VSD loading (di-1-ANEPPQ $)^{50}$ via patch pipettes was performed as described previously ${ }^{21}$ but with the internal solution supplemented with the $\mathrm{Na}^{+}$channel blocker QX314. For VSD electroporation, a solution containing $5 \mathrm{mg} \mathrm{ml}^{-1}$ of di-1-ANEPPQ in the recording internal solution was loaded into glass pipettes and injected into pyramidal cells from a distance of $5-10 \mu \mathrm{m}$ by applying $1-3+10-\mathrm{mV}, 500-\mu \mathrm{s}$ pulses in the vicinity of cell somas. After electroporation, we allowed the tissue to rest for 1.5-2 $\mathrm{h}$ before recordings to assure VSD spread into the dendrite. Image series, acquired by a sCMOS camera or an EM-CCD (Neo), were produced by exciting the sample with a $200-\mathrm{W}$ metal-halide lamp through a bandpass filter centered at $535 \mathrm{~nm}(\sim 510-560-\mathrm{nm}$ pass $)$ and collecting the emission through a long-pass filter (590-nm cut-off) or using an LED array (627 nm, Luxeon) excitation source through a ET640/30x filter (Chroma), a Q680LP splitter and a HQ705LP emission filter (Chroma). Image acquisition and extracellular stimulation was synchronized through transistor-transistor logic pulses. To guarantee time precision, the stimulator and the camera 'fire' outputs (that flags image acquisition) were recorded using a National Instruments DAQ card and custom imaging/electrophysiology software (KiaFluo $)^{51}$. All electrophysiology and voltage-imaging experiments were performed at $30^{\circ} \mathrm{C}$.

Single-cell reverse-transcription PCR. External and internal solutions used for experiments in which cells were collected for single-cell PCR were filtered with a $0.2-\mu \mathrm{m}$ pore diameter filter. After recordings, the cytoplasm and organelles were sucked into the recording pipette tip as previously described $^{52}$. Pipettes were quickly removed and tips were broken into 1.5-ml tubes containing freshly prepared solution of $20 \mathrm{U}$ of RNase inhibitor and $8.3 \mathrm{mM}$ DTT; samples were frozen immediately on dry ice and stored at $-80{ }^{\circ} \mathrm{C}$ until use. The samples were thawed on ice and the RNA was converted to cDNA by reverse transcription for $1 \mathrm{~h}$ using $0.5 \mathrm{mM}$ dNTP mix, $1.25 \mu \mathrm{M}$ random primers, $40 \mathrm{U}$ of RNase inhibitor, $100 \mathrm{U}$ of M-MLV reverse transcriptase (Invitrogen), $50 \mathrm{mM}$ Tris- $\mathrm{HCl}, 75 \mathrm{mM} \mathrm{KCl}$ and $3 \mathrm{mM}$ $\mathrm{MgCl}_{2}, \mathrm{pH}$ 8.3. The reverse transcriptase enzyme was denatured and the cDNAs stored at $-80^{\circ} \mathrm{C}$ until use. A first round of PCR was performed using $1.5 \mathrm{mM} \mathrm{MgCl}_{2}, 10 \mathrm{pmol}$ of each primer, $1.0 \mathrm{U}$ of platinum Taq-DNA polymerase (Invitrogen), $20 \mathrm{mM}$ Tris- $\mathrm{HCl}$ and $50 \mathrm{mM} \mathrm{KCl}, \mathrm{pH}$ 8.4. Thermal cycles consisted of an initial denaturation step of $94^{\circ} \mathrm{C}$ for $2 \mathrm{~min}$, followed by 35 cycles of $94^{\circ} \mathrm{C}$ for $50 \mathrm{~s}, 55^{\circ} \mathrm{C}$ for $45 \mathrm{~s}$ and $72{ }^{\circ} \mathrm{C}$ for $45 \mathrm{~s}$. A second nested PCR was then performed as mentioned above using $10 \%$ of the first PCR reaction as template. All PCR products were resolved on $2.5 \%$ agarose gels. Primers were designed on the basis of sequences deposited in the GenBank database (http://www.ncbi.nlm.nih.gov/nucleotide). The Gad67 primers used were GAD67nl-up CCAATAGCCTGGAAGAGAAGAG; GAD67nl-lw TCCCATCACCATCTTTATTTGA to generate the first round product and GAD67s-up GTCCTCCAAGAACCTGCTTTC; GAD67s-lw TCAGCCATTCACCAGCTAAAC to generate the second round product.

In situ hybridization. Construction of in situ probes is described elsewhere ${ }^{53}$. The Viaat clone is commercially available at Invitrogen (clone ID: 5717808) and corresponds to nucleotides 2021-2805 (NM_009508). The mouse Som full-length cDNA clone IRAVp968G0228D was obtained from Source BioSciences. Antisense and sense transcripts were generated by in vitro transcription using either T7 or SP6 polymerase and labeled with digoxygenin (Roche) following manufacturer's instructions to make in situ hybridization probes. Both sense and antisense probes were tested on adjacent brain sections and the specificity of the antisense in situ hybridization probe was verified (data not shown). The floating in situ hybridization was carried out as previously described ${ }^{54}$, with the exclusion of the graded methanol series and with the hybridization temperature set to $58^{\circ} \mathrm{C}$. Signal detection was made by Fast Red tablets (Roche Diagnostics Scandinavia). After development, the tissue was washed in phosphate-buffered saline with Tween-20 (0.1\%, MP Biomedicals) and mounted on glass slides. Sections were subsequently stained with rabbit antibody to red fluorescent protein (Abcam, catalog no. ab62341, 1:200) to re-visualize the Tomato $^{+}$neurons that were bleached by the in situ hybridization protocol. Next, slices were incubated $3 \mathrm{~h}$ at $18-23^{\circ} \mathrm{C}$ in secondary antibody (Alexa 488-conjugated donkey antibody to rabbit, Invitrogen, 1:400). 
Images were collected on a Zeiss LSM 510 Meta confocal microscope and stacked using Volocity software (Improvision) and edited in Photoshop CS3 (Adobe), where the color palette was adjusted for consistency.

Virus injection. Chrna2-cre and Chrna2-cre; Viaat ${ }^{l o x P}$ /loxP mice (1-2 months old), sometimes crossed with $R 26^{\text {tom }}$ reporter mice, were anesthetized with a cocktail of one part of Hypnorm (fentanyl citrate, $0.315 \mathrm{mg} \mathrm{ml}^{-1}$; fluanisone, $10 \mathrm{mg} \mathrm{ml}^{-1}$; VetaPharma), one part of midazolam $\left(5 \mathrm{mg} \mathrm{ml}^{-1}\right)$ in two parts of distilled water (subcutaneous injection of $0.075 \mathrm{ml}$ per $10 \mathrm{~g}$ of weight). Animals were placed in a stereotaxic frame (Stoelting) and viral particles $\left(1.6 \times 10^{13}\right.$ particles per $\mathrm{ml}$ of AAV2/9.EF1a.DIO.hChR2(H134R)-EYFP.WPRE.hGH (Addgene vector 20298) obtained from the University of Pennsylvania Vector Core Facility) were injected unilaterally into the dorsal hippocampus (CA1) using the following bregma coordinates: $-3.2 \mathrm{~mm}$ antero-posterior, $+3.8 \mathrm{~mm}$ medio-lateral and $3.6 / 2.6 \mathrm{~mm}$ dorso-ventral. Virus solution $(0.75 \mu \mathrm{l}$ per injection depth) was delivered at a flow rate of $200 \mathrm{nl} \mathrm{min}^{-1}$ using an electronic pump (World Precision Instruments) equipped with a 10- $\mu 1$ Hamilton syringe. After infusion, the needle was left in place for $1 \mathrm{~min}$. The scalp incision was sutured and animals were housed in special containment cages after recovering from anesthesia. In vitro recordings were performed within 10-14 d of virus injection.
Statistical analysis. Statistical analysis of electrophysiology data was performed by two-tailed paired or unpaired $t$ tests (homogeneity of variances was tested using Levene's test). Data are presented as mean \pm s.e.m.; $P \leq 0.05$ was considered to be statistically significant.

48. Marshall, V.M., Allison, J., Templeton, T. \& Foote, S.J. Generation of BAC transgenic mice. Methods Mol. Biol. 256, 159-182 (2004).

49. Leão, R.N., Tan, H.M. \& Fisahn, A. Kv7/KCNQ channels control action potential phasing of pyramidal neurons during hippocampal gamma oscillations in vitro. J. Neurosci. 29, 13353-13364 (2009).

50. Zhou, W.L., Yan, P., Wuskell, J.P., Loew, L.M. \& Antic, S.D. Intracellular longwavelength voltage-sensitive dyes for studying the dynamics of action potentials in axons and thin dendrites. J. Neurosci. Methods 164, 225-239 (2007).

51. Leão, R.N. et al. A voltage-sensitive dye-based assay for the identification of differentiated neurons derived from embryonic neural stem cell cultures. PLOS ONE 5, e13833 (2010).

52. Leão, R.N., Colom, L.V., Borgius, L., Kiehn, O. \& Fisahn, A. Medial septal dysfunction by Abeta-induced KCNQ channel-block in glutamatergic neurons. Neurobiol. Aging 33, 2046-2061 (2012).

53. Gezelius, H., Wallen-Mackenzie, A., Enjin, A., Lagerstrom, M. \& Kullander, K. Role of glutamate in locomotor rhythm generating neuronal circuitry. J. Physiol. Paris 100, 297-303 (2006).

54. Enjin, A. et al. Identification of novel spinal cholinergic genetic subtypes disclose Chodl and Pitx2 as markers for fast motor neurons and partition cells. J. Comp. Neurol. 518, 2284-2304 (2010). 